\title{
DEKONSTRUKSI SASTRA ANAK: MENGUBAH PARADIGMA KEKERASAN DAN SEKSUALITAS PADA KARYA SASTRA ANAK INDONESIA
}

\author{
Citra Nur Faidah \\ Email avenasativa96@gmail.com
}

\author{
Prodi Pendidikan Bahasa Indonesia, Pascasarjana \\ Universitas Negeri Malang, Indonesia
}

\begin{abstract}
Abstrak
Sastra merupakan ungkapan perasaan seseorang yang dituangkan dalam sebuah tulisan maupun cerita yang dikemas secara menarik pembacanya. Tidak jauh berbeda dengan sastra, sastra anak merupakan ungkapan perasaan seorang anak yang dituangkan kedalam bentuk tulisan dan dinikmati oleh anak-anak. Bentuk sastra anak yang terdapat di Indonesia sangatlah beragam diataranya seperti puisi, cerpen, novel, dongeng, fabel dll. Dewasa ini banyak sekali cerita anak yang mengandung unsur kekerasan didalamnya. komik merupakan salah satu contoh cerita anak yang digemari di dunia tak terkecuali juga di Indonesia. Banyak sekali ditemukan buku komik yang memiliki gambar- gambar dan cerita menyimpang yang tidak layak dikonsumsi oleh pembaca khususnya anak- anak, dalam hal ini kekerasan mendominasi perkembangan komik di Indonesia. Cerita rakyat yang diperuntukkan untuk anak-anak tentu ada yang aman bagi anak dan ada pula yang tidak aman. Meskipun cerita rakyat sebuah cerminan budaya, beberapanya dalam konteks kini malah berpotensi meninggalkan kesan tidak baik karena saratnya beberapa cerita mengandung seksualitas, kekerasan, iri dan dengki. Perlu adanya dekonstruksi sastra untuk mengubah cerita sehinga tidak terdapat unsur kekerasan dan unsur seksualitas dalam cerita anak. Dekonstruksi sastra dilakukan dengan mengubah tema-tema yang berkembang selama ini, serta menghapus adegan -adegan yang mengandung unsur kekerasan.
\end{abstract}

\begin{abstract}
Literature is an expression of one's feelings as outlined in an article or story that is attractively packaged by the reader. Not much different from literature, children's literature is an expression of a child's feelings that are poured into written form and enjoyed by children. The forms of children's literature contained in Indonesia are very diverse, such as poetry, short stories, novels, fables, etc. Today there are many stories about children that contain elements of violence in them. comics is one example of the story of a popular child in the world, including in Indonesia. There are so many comic books found that have distorted images and stories that are not suitable for consumption by readers, especially children, in this case violence dominates the development of comics in Indonesia. The folklore shown for children is certainly safe for children and some are unsafe. Although folklore is a reflection of culture, some in the context of the present has the potential to leave a bad impression because some stories contain sexuality, violence, idiosyncrasies. It is necessary to have literary deconstruction to change the story so that there is no element of violence and elements of sexuality in children's stories. Literary doctrine is done by changing the themes that have developed so far by making changes and removing scenes that contain elements of violence.
\end{abstract}

\section{PENDAHULUAN}

Sastra merupakan ungkapan perasaan seseorang yang dituangkan dalam sebuah tulisan maupun cerita yang dikemas secara menarik pembacanya. Tidak jauh berbeda dengan sastra, sastra anak merupakan ungkapan perasaan seorang anak yang dituangkan kedalam bentuk tulisan dan dinikmati oleh anak-anak. Sastra anak juga merupakan karya sastra yang ditulis oleh orang dewasa dan diperuntukkan oleh anak-anak, atau karya sastra yang ditulis oleh anak-anak dan dinikmati oleh anakanak. Sastra anak merupakan sebuah karya sastra yang menawarkan kesenangan dan pemahaman. Kurniawan (2013:23) mengemukakan bahwa sastra anak merupakan sebuah karya sastra yang ceritanya berkolerasi dengan dunia anak-anak dan bahasa yang digunakan sesuai dengan perkembangan intelektual, dan emosional anak. 
Sastra anak sebenarnya sudah lama ada di Indonesia. Sastra anak yang berkembang di Indonesia tidak seperti sastra anak yang berkembang di luar negeri. Bentuk sastra anak yang terdapat di Indonesia sangatlah beragam diantaranya seperti puisi, cerpen, novel, dongeng, fabel dll. Lukens (2003:30) mengemukan bahwa secara garis besar genre sastra anak terbagi menjadi lima macam, yaitu fiksi, non fiksi, puisi, sastra tradisional, komik. Fiksi merupakan bentuk prosa. Jika dilihat dari ceritanya menampilkan cerita hayalan atau cerita imajinatif. Cerita fiksi anak yang berkembang di luar negeri maupun di Indonesia sangatlah beragam. Hal ini terbukti dengan banyaknya jenis fiksi dalam fiksi anak. Fiksi fantasi misalnya, fiksi fantasi $50 \%$ lebih banyak terdapat pada negara maju khususnya di negara benua Eropa. Contoh fiksi fantasi seperti Harry Potter, badman, superman, dll. Fiksi ilmiah misalnya, fiksi ilmiah banyak berkembang di negara negara asia seperti Jepang, Korea, Taiwan dll. Berkembangnya beberapa fiksi anak di dunia akan mempengaruhi perkembangan fiksi anak. di Indonesia. Aminuddin (2001:29) mengemukakan bahwa cerita fiksi anak terbagi kedalam lima jenis, yaitu(1) fiksi ilmiah, (2) fiksi sejarah, (3) fiksi sejarah, (4) fiksi formula, (5) cerita fantasi.

\section{KERANGKA TEORI}

Nonfiksi
karangan yang jika dilihat dari
bentuknya nonfiksi juga berbentuk
prosa namun ceritanya bukan cerita
imajinatif. Lukens $(2003: 14)$
mengemukakan bahwa nonfiksi
adalah sebuah karangan realisme

(realisme sejarah, realisme olahraga), serta karya yang berbentuk buku informasi seperti biografi. Biografi merupakan cerita yang memuat informasi tentang kehidupan seseorang. Melalui cerita nonfiksi seorang anak dapat mengetahui informasi mengenai tokoh-tokoh tertentu yang dapat menginspirasi mereka. Aminuddin (2001:32) mengemukakan bahwa biografi bukan hanya tokoh yang terkenal namun bisa seperti orang tua, nenek, guru dll.

Puisi anak merupakan pengungkapan sesuatu dari kacamata anak. Puisi anak ditulis dalam bentuk bait-bait. Bahasa yang digunakan sederhana, pendek dan penuh dengan irama. Nurgiyantoro (2016:314) mengemukakan bahwa puisi anak ditulis dengan bahasa singkat, lariknya pendek yang mungkin membentuk bait-bait, tematema yang sederhana yang sesuai dengan kejadian sehari-hari, tipografi yang pendek.

Sastra tradisional adalah cerita rakyat yang tidak jelas kapan diciptakannya dan tidak pernah diketahui pengarangnya yang diwariskan secara turun-temurun terutama lewat saran lisan atau dalam tulisan. Lukens (2003:32) mengemukakan bahwa bentuk cerita tradisional terbagi menjadi 4 jenis, yaitu (1) cerita rakyat, (2) dongeng, (3) legenda, (4) mite. Sastra tradisional merupakan karya sastra yang paling banyak berkembang di Indonesia. Sastra tradisional yang berkembang di Indonesa merupakan karya sastra yang paling berpengaruh terhadap pembentukan karakter anak di Indonesia. Sastra tradisional seperti mitos, legenda, cerita binatang, dongeng, nyanyian rakyat dan sebagainya, yang hidup di dalam 
suatu masyarakat diyakini oleh masyarakat memiliki nilai-nilai kearifan dan nilai-nilai edukasi yang dapat digunakan untuk menumbuhkembangkan nilai nilai personal anak. Sawirta (2006:19) mengemukakan bahwa sastra tradisional yang berkembang di Indonesia sangat membentuk karakter anak.

Komik adalah cerita bergambar dengan sedikit tulisan, bahkan kadang-kadang ada gambar yang tanpa tulisan. Rangkaian gambar pada komik biasanya didominasi oleh gambar aksi membentuk sebuah alur cerita. Alur cerita pada komik dikembangkan atau ditunjukkan lewat rangkaian gambar aksi dan kata. Nurgiyantoro (2016:33) mengemukakan bahwa jenis komik jika dilihat melalui isi cerita dapat dikategorikan menjadi komik fiksi dan komik non fiksi.

Sejarah lahirnya sastra anak masih belum diketahui pastinya. Namun, kita ketahui bersama bahwa cerita itu lahir dari impian, harapan, duka cita. Cerita anak bermula dari cerita nenek moyang kita mengisahkan pengalaman, petualangan. Bercerita secara lisan yang dilakukan oleh nenek moyang secara tidak langsung dapat menanamkan rasa persaudaraan.

Sastra anak berkembang mulai dari cerita-cerita yang disampaikan secara lisan dan dipercaya hingga turun-temurun. Cerita yang disampaikan secara lisan biasanya berkisah tentang kisahkisah sedih, berani, dan fantasi. Sejak jaman prasejarah cerita lisan hingga abad ke 15 cerita anak yang beredar dikalangan masyarakat berbentuk cerita lisan. Hal ini terbukti dengan banyaknya cerita yang selama ini kita kenal dengan cerita Putri Salju, Cinderella, dan lain-lain. Kisah kisah tersebut bermula dari cerita lisan yang diceritakan oleh orang dewasa untuk anaknya sebagai pengantar tidur. Menurut para ahli cerita yang dituturkan secara lisan dan disampaikan dari mulut ke mulut dapat ditemukan pada hampir segala jenis budaya diseluruh dunia. Termasuk juga di Indonesia. Dan hal ini tidak diketahui asal muasalnya.

Cerita anak yang diceritakan secara lisan menjadi yang paling diminati. Pada tahun 1967 penulispenulis seperti Charles Perrault (dari perancis), Josep Jacobs (dari Inggris), Andrew Lng (Inggris) misalnya, mereka memelihara cerita lisan yang beredar di kalangan mereka "Cinderella", Snow White, "Si Tudung Merah" yang diterbitkan oleh Charles Perrault sudah mulai beralih wahana. Cerita -cerita tersebut mulai ditulis ulang dan terbitkan menjadi sebuah buku sehingga untuk pertama kalinya anak-anak di dunia dapat membaca dan menikmati buku tersebut. Fenomena ini membuat sastra anak yang dulunya hanya diceritakan dari mulut ke mulut. Sekarang sudah berubah menjadi buku dan dapat dinikmati oleh anak-anak.

Bermula dari tradisi lisan yang menjadi tradisi tulis. Cerita anak juga berkembang. Pada abad ke 17 dan 18 cerita anak mulai berkembang. Sarumpaet (2010:90) mengemukakan bahwa buku cerita yang diterbitkan pada abad ini berupa buku cerita yang mengajarkan tentang agama, keselamatan jiwa anak-anak. Bukubuku seperti ini berlanjut hingga abad 18 pertengahan. Banyak buku yang menerbitkan cerita tentang peri dan petualangan. Seperti Tales of 
Mother Goose yang diterbitkan oleh Charles Perrault pada tahun 1679, A little Pretty Pocket Books yang diterbitkan oleh John Nowberry pada tahun 1744. Buku yang menjelaskan tentang keagamaan sengaja dibuat untuk membentuk karakter anak agar percaya terhadap kekuatan tuhan pada saat itu.

Pada tahun 1846 mulai terbit buku yang menceritakan tentang keluarga seperti cerita Liltle Woman karya Loisa May Alcott, The Swiss Family Robinson karya Johan David. Cerita anak di dunia semakin berkembang. Cerita anak sengaja dibuat dan diterbitkan dengan mementingkan unsur didaktis di dalamnya karena cerita anak akan mempengaruhi karakter bangsa kedepannya.

Cerita anak dari tahun ke tahun semakin menunjukkan kesuburan. Pada tahun 1864 penulis buku anak mulai terkenal dan digemari oleh masyarakat. Salah satunya Alice`s Andventure In the Wonderland. Cerita-cerita ini begitu mashur hingga saat ini. Cerita-cerita inilah yang mengubah buku cerita mulai beralih wahana menjadi film anak-anak yang dibuat dengan unsur didaktis di dalamnya. Penulis pada abad ini sengaja menulis karya sastra anak dengan memasukkan unsur didaktis agar anak-anak mendapatkan bekal dengan membaca suatu karya satstra.

Tak jauh berbeda dengan perkembangan bacaan anak di dunia. Bacaan anak di Indonesia berkembang setiap zamannya. Pada tahun 1905 cerita anak-anak yang berkembang di Indonesia berupa cerita yang tidak tahu darimana cerita tersebut berasal. Cerita tersebut hanya berupa dongeng yang diceritakan secara lisan dari mulut ke mulut. Winarni (2014:77) mengemukakan bahwa sastra anak indonesia bermula dari cerita lisan yang diceritakan dari mulut ke mulut yang berlangsung cukup lama hingga tahun 1800-an.

Sastra anak di Indonesia mulai berkembang pada tahun 1945 . Anak-anak mulai mengenal cerita cerita yang mengandung unsur didaktis. Cerita anak yang berkembang seperti dongeng, buku cerita, dan buku-buku terjemahan dari luar negeri.

Pada tahun 1945 buku bacaan anak dianggap kurang memadai. Buku bacaan anak masih sangat langka. Kalaupun ada isi yang terdapat dalam buku bacaan cenderung mengedepankan pendidikan dan pengajaran terutama pengajaran moral. Hal ini terbukti dengan adanya buku-buku adaptasi dari luar negeri yang diterjemahkan oleh Indonesia.

Perkembangan sastra anak pada tahun dimana masa penjajahan telah berakhir dianggap juga kurang diperhatikan. Hal ini terjadi karena minimnya jumlah buku bacaan anak. Anak-anak dapat menikmati karya sastra hanya menggunakan buku pelajaran bahasa Indonesia saja. Sarumpaet (2017:54) mengemukakan bahwa perkembangan sastra anak di Indonesia masih memprihatinkan. Jarangnya penulis sastra anak yang menyebabkan sastra anak belum diperhitungkan dalam dunia sastra. Kurang berkembangnya sastra anak menyebabkan tidak hadirnya fakta yang ada memang demikian. Para penulis cerita anak di media cetak (surat kabar, majalah) hampir tidak terlihat dari para pengamat sastra dan kritikus sastra. Cerita anak yang hadir di media cetak berlalu begitu 
saja, apresiasi terhadap karya-karya sastra anak yang ada di media cetak jarang dibicarakan. Seakan sastra anak tidak ada nilainya. Cerita anak yang berkembang pada abad ke 20 khususnya di Indonesia masih terbilang cukup tertinggal diantara negara-negara maju yang lain. Cerita yang berkembang hanya masih banyak mengangkat cerita-cerita legenda daripada cerita fantasi. Hal ini menunjukkan bahwa sastra anak di Indonesia kurang diperhatikan dan kurang diminati.

Perkembangan sastra anak pada saat ini seakan-akan tidak ada nilainya. Padahal sebenarnya sastra mempunyai kontribusi yang sangat besar. Kontribusi sastra sangat besar terhadap kemajuan peradaban umat manusia pada masa kini, terutama pada masa mendatang. Hal itu karena sastra anak memberikan kontribusi pada perkembangan emosional anak, intelektual, imajinasi, rasa sosial, membentuk kepribadian luhur, membangun kreativitas anak, sehingga sastra anak yang baik, berkualitas berdampak multidimensi dalam kehidupan anak sekarang ini dan berlanjut pada masa mendatang. Kurniawan (2013:06) mengemukakan bahwa sastra anak dapat memberikan kontribusi pada perkembangan emosional anak, intelektual, imajinasi, rasa sosial, membentuk kepribadian luhur, membangun kreativitas anak sehingga dapat tercipta generasi penerus bangsa yang unggul.

Sastra anak berperan penting membangun sumber daya manusia sejak dini. Kehadiran sastra anak sejatinya tidak hanya sekadar hadir tetapi eksistensi sastra anak luar biasa dampak yang dihasilkannya. Hal ini harus disadari semua pihak, dari orang tua, pendidik, pemerintah dan juga para sastrawan Indonesia bagaimana melahirkan sumber daya manusia masa depan yang kualitasnya lebih baik. Salah satu cara untuk menghasilkan sumber daya manusia masa depan yang kualitasnya lebih baik adalah dengan menggunakan sastra anak. Sastra anak dapat dijadikan sebagai media untuk mendidik dan mengajarkan nilai-nilai kehidupan melalui sastra. Anak-anak dapat mengembangkan kemampuan imajinasi, intelektual, emosional, dan belajar mengidenfikasi diri sendiri melalui karya sastra yang telah didengar dan dibacanya.

Sastra anak berpengaruh terhadap perkembangan emosi anak. Anak usia dini yang belum dapat berbicara, atau baru berada dalam tahap perkembangan bahasa satu kata atau kalimat dalam dua-tiga kata, sudah ikut tertawa-tawa ketika diajak bernyanyi bersama sambil bertepuk tangan. Anak tampak menikmati lagu-Iagu bersajak yang ritmis dan larut dalam kegembiraan. Hal itu dapat dipahami bahwa sastra lisan yang berwujud puisi-Iagu tersebut dapat merangsang kegembiraan anak, merangsang emosi anak untuk bergembira, bahkan ketika anak masih berstatus bayi. Emosi gembira yang diperoleh anak tersebut penting karena hal itu juga akan merangsang kesadaran bahwa ia dicintai dan diperhatikan.

Pertumbuhan kepribadian anak tidak akan berlangsung secara wajar tanpa cinta dan kasih sayang oleh orang di sekelilingnya. Dalam perkembangan selanjutnya setelah anak dapat memahami cerita, baik diperoleh lewat pendengaran misalnya diceritai atau dibacakan, maupun lewat kegiatan rnembaca sendiri, anak akan memperoleh 
demonstrasi kehidupan sebagaimana yang diperagakan oleh para tokoh cerita tokoh-tokoh cerita akan bertingkah laku baik secara verbal maupun nonverbal yang rnenunjukkan sikap emosionalnya, seperti ekspresi gembira, sedih, takut, terharu, simpati dan empati, benci dan dendam, memaafkan, dan lain-lain secara kontekstual sesuai dengan alur cerita. Tokoh protagonis akan menampilkan tingkah laku yang baik, sebaliknya tokoh antagonis menampilkan tingkah laku yang kurang baik. Pembaca anak akan mengidentifikasikan dirinya kepada tokoh protagonis sehingga sikap dan tingkah laku tokoh itu seolah-olah diadopsi menjadi sikap dan tingkah lakunya.

Sasita

mengemukakan bahwa sastra anak memiliki kontribusi yang besar bagi perkembangan kepribadian anak dalam proses menuju kedewasaan. Sastra anak diyakini mampu digunakan sebagai salah satu sarana untuk menanam, memupuk, mengembangkan, dan bahkan melestarikan nilai-nilai pendidikan yang baik dan sangat berharga oleh keluarga, masyarakat, dan bangsa. Adanya pewarisan nilai-nilai pendidikan itulah eksistensi suatu masyarakat dan bangsa dapat dipertahankan.

\section{HASIL DAN PEMBAHASAN}

\section{KEKERASAN DAN SEKSUALITAS PADA KARYA SASTRA ANAK}

\section{Kecenderungan Pola Sastra Anak Indonesia}

Cerita anak begitu penting dalam perkembangan anak. Mereka dapat mengambil amanat dari cerita yang mereka baca. Mereka dapat mengubah kehidupan mereka kedepan melalui kekuatan cerita yang mereka baca. Namun bacaan cerita anak di Indonesia masih kurang diperhatikan. Karakteristik sastra anak setiap tahunnya tidak banyak menunjukkan perubahan bahkan hampir tidak terdapat perubahan di setiap tahunnya.

Sampai saat ini buku sastra anak yang bermunculan sangat beragam. Buku sastra anak bisa berbentuk novel anak, cerita pendek anak atau kumpulan cerita pendek anak, puisi anak ataupun ragam lainnya. Ragam sastra anak ini tidak terbatas pada bentuk buku saja, tetapi juga terdapat dalam majalah anak, misalnya majalah "Bobo", "Mentari", dan majalah anak lainnya. Hal ini terbukti dengan banyaknya cerita anak yang dapat ditemukan dalam buku kumpulan cerita anak ataupun majalah anak-majalah anak, salah satu cerita anak yang berkembang di Indonesia adalah cerita fantasi, dongeng, fabel dan lain-lain.

Sarumpaet (2017:88) yang mengungkapkan bahwa karakteristik cerita anak di Indonesia pada dewasa ini lebih banyak mengangkat cerita fantasi. Karakteristik cerita fantasi yang berkembang di Indonesia juga beragam namun masih jauh dari perkembangan sastra anak di dunia. Minimnya buku bacaan anak mempengaruhi perkembangan cerita anak di Indonesia. Hal inilah yang memunculkan keanekaragaman karakteristik cerita anak.

Alurnya yang digunakan dalam cerita fantasi anak Indonesia dewasa ini lebih banyak menggunakan alur maju atau linier. Tokoh yang digunakan dalam cerita anak Indonesia adalah manusia, 
binatang, dan peri. Tokoh berupa binatang dan peri dalam cerita fantasi anak dipersonifikasikan seperti manusia. Penokohan dalam cerita fantasi anak Indonesia menggunakan teknik analitik dan dramatik secara bersama-sama. Watak tokoh dalam cerita anak Indonesia ada yang berkembang dan ada yang tidak berkembang. Latar tempat yang digunakan dalam cerita anak Indonesia berupa rumah, istana, taman, dan hutan. Latar waktu yang digunakan adalah pagi hari, siang hari, sore hari, malam hari, dan suatu hari.

Tema yang digunakan dalam cerita anak Indonesia ada empat macam. Pertama, berbuat tidak baik kepada orang lain akan mendatangkan kerugian pada diri sendiri. Kedua, orang yang berbuat baik kepada orang lain akan mendapatkan kebaikan pula. Ketiga, orang yang tidak pandai mensyukuri apa yang dimiliki akan mudah tergoda dengan apa yang dimiliki oleh orang lain. Keempat, orang yang sabar dan berusaha dalam melakukan suatu pekerjaan pasti akan mendapatkan balasan yang setimpal. Amanat yang ditampilkan dalam cerita anak Indonesia ada empat macam. Pertama, kita tidak boleh berbuat usil pada orang lain. Kedua, kita harus saling tolong menolong. Ketiga, kita tidak boleh mudah tergoda oleh kemewahan orang lain. Keempat, kita harus berusaha dan sabar dalam mengerjakan sesuatu.

\section{Sisi Positif Sastra Anak}

Sastra anak mempunyai sisi positif bagi pembacanya. Bagi anakanak bacaan anak atau cerita anak mempunyai banyak manfaat diantaranya sebagai fungsi hiburan dan fungsi pendidikan. Lukens (2003:76) mengemukakan bahwa sastra anak mempunya manfaat bagi penikmatnya, yaitu fungsi hiburan dan fungsi pendidikan. Sastra anak mempunyai manfaat sebagai hiburan diantaranya, (1) memberi kesenangan, kegembiraan, dan kenikmatan bagi anak-anak, (2) mengembangkan imajinasi anak dan membantu mereka mempertimbangkan dan memikirkan alam, kehidupan, pengalaman atau gagasan dengan berbagai cara, (3) memberikan pengalaman baru yang seolah dirasakan dan dialaminya sendiri, (4) mengembangkan wawasan kehidupan anak menjadi perilaku kemanusiaan, menyajikan dan memperkenalkan anak terhadap pengalaman universal dan warisan budaya.

Sastra anak berfungsi bukan hanya sebagai hiburan saja. Sastra anak juga berfungsi sebagai pendidikan. Sastra anak memberi banyak informasi tentang sesuatu hal, yakni memberikan banyak pengetahuan, memberikan kreativitas atau keterampilan anak, dan memberikan pendidikan moral pada anak. Sastra anak juga bernilai ekstrinsik yang bermanfaat untuk perkembangan anak terutama dalam hal (1) perkembangan bahasa, (2) perkembangan kognitif, perkembangan kepribadian, dan (4) perkembangan sosial. Sastra yang terwujud untuk anak-anak selain ditujukan untuk mengembangkan imajinasi, fantasi dan daya kognisi yang akan mengarahkan anak pada pemunculan daya kreativitas juga bertujuan mengarahkan anak pada pemahaman yang baik tentang alam dan lingkungan serta pengenalan pada perasaan dan pikiran tentang diri sendiri maupun orang lain. 


\section{Sisi Negatif Sastra Anak}

Cerita anak yang berkembang di Indonesia bukan hanya mempunyai fungsi positif namun juga negatif. Sastra anak mempunyai fungsi negatif jika cerita anak disajikan dengan mengandung unsurunsur yang negatif didalamnya. Anak-anak bagaikan kertas putih. Jika anak-anak membaca cerita dan didalam cerita tersebut mengandung hal-hal yang negatif seperti unsurunsur kekerasan dan unsur-unsur seksualitas maka tidak menutup kemungkinan anak-anak meniru apa yag telah dibacanya.

$$
\text { Cerita anak begitu }
$$

berpengaruh terhadap tumbuh kembang anak. Cerita anak dapat merusak generasi anak kedepannya karena kekuatan dari cerita yang telah dibacanya. Jika cerita anak tersebut mengandung kekerasan dan seksualitas didalam cerita tersebut maka besar kemungkinan anak-anak untuk mencari tahu, dan jika anak itu kritis maka anak itu akan mencoba mempratikkannya. Hal inilah yang akan merusak generasi anak-anak di masa depan. Secara tidak langsung cerita anak berpengaruh terhadap perkembangan moral anak. Winarni (2014:66) mengemukakan bahwa cerita anak berpengaruh besar terhadap perkembangan moral anak. Cerita anak-anak yang baik seharusnya dapat mengubah moral anak menjadi berkualitas.

\section{Unsur Kekerasan dalam Cerita Anak}

Dewasa ini banyak sekali cerita anak yang mengandung unsur kekerasan didalamnya. Komik merupakan salah satu contoh cerita anak yang digemari di dunia tak terkecuali juga di Indonesia. Buku komik mayoritas menjadi bacaan favorit anak-anak justru menyajikan gambar- gambar kekerasan yang mampu mempengaruhi perilaku dan psikis mereka.

Konten yang terdapat dalam cerita komik di Indonesia banyak sekali memperlihatkan gambargambar perkelahian perkelahian yang berakhir dengan kematian seperti pada gambar dibawah ini

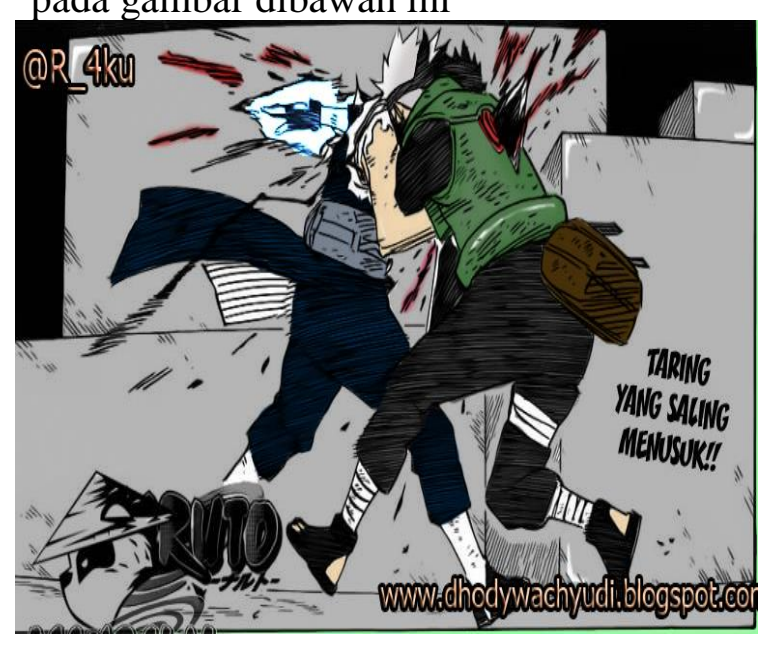

Padahal kebanyakan pembaca komik kebanyakan adalah anak- anak yang sebenarnya belum diperbolehkan untuk mengetahui gambar- gambar kekerasan seperti itu, karena akan berdampak buruk bagi perkembangan psikis mereka. Cerita yang disajikan dalam bacaan komik juga banyak menunjukkan kekerasan. Terdapat beberapa adegan kekerasan seperti serangan memukul dan menggunakan senjata. Hal inilah yang nantinya akan berdampak buruk bagi anak-anak. Anak-anak dapat meniru adegan seperti mereka baca dalam komik tersebut. Tak jarang banyak sekali anak-anak yang berkelahi dengan teman sebaya karena seringnya membaca komik yang mengandung unsur kekerasan.

Kekerasan yang terdapat dalam cerita anak akan merusak moral anak-anak. Hal Ini terbukti dengan banyaknya anak-anak pada 
dewasa ini sering sekali berkelahi dengan teman sebayanya. Bahkan yang lebih parahnya lagi, banyak guru yang dianiaya oleh muridnya sendiri. Contoh perilaku menyimpang inilah dampak dari cerita anak yang didalamnya terdapat unsur kekerasan. Anak-anak meniru apa yang telah mereka baca. Jika cerita-cerita yang mereka baca mengandung unsur kekerasan, tak hayal nantinya anak-anak akan banyak melakukan kekerasan terhadap orang lain yang dilakukan pada kehidupan sehari-hari mereka.

\section{Unsur Seksualitas dalam Cerita Anak}

Cerita anak di Indonesia tidak hanya dihantui oleh unsur kekerasan namun cerita anak yang berkembang di Indonesia juga masih mengandung unsur seksualitas. Cerita rakyat di Indonesia misalnya, banyak sekali cerita yang mash mengandung unsur seksualitas. Seperti pada cerita rakyat timun emas. Pada cerita tersebut diceritakan Sarumpaet (2017:98) mengemukakan bahwa terdapat 365 cerita rakyat di Indonesia. Cerita rakyat yang ditunjukkan untuk anakanak tentu ada yang aman bagi anak dan ada pula yang tidak aman. Meskipun cerita rakyat sebuah cerminan budaya, beberapanya dalam konteks kini malah berpotensi meninggalkan kesan tidak baik karena saratnya beberapa cerita mengandung seksualitas, kekerasan,iri dan dengki. Unsur seksualitas dalam cerita rakyat tidak ditunjukkan secara langsung namun secara tersirat. Seperti pada cerita rakyat Jaka Tarub, Sangkuriang, Timun Mas. Pada cerita tersebut mengangkat cerita tentang percintaan yang terhadap lawan jenis. Cerita ini secara tidak langsung mengandung

134 | Jurnal Kredo Vol. 2 No. 1 Oktober 2018 unsur seksualitas didalamya. Cerita seperti ini seharusnya tidak dikonsumsi oleh anak-anak.

Cerita rakyat yang berkembang Indonesia biasanya banyak digunakan oleh orang tua untuk media pembelajaran. tidak semua cerita rakyat yang berkembang di masyarakat cocok untuk anak-anak. Perlu adanya pemilihan cerita rakyat yang cocok untuk anak. Adanya pemilihan cerita rakyat terhadap anak diharapkan nantinya tidak ada lagi unsur-unsur seksualitas didalamnya. Unsurseksualitas yang terdapat dalam cerita rakyat di Indonesia sangatlah banyak. Kisah-kisah tersebut diantaranya (1) kisah Sangkuriang, (2) Jaka Tarub, (3) Timun emas dan lain sebagainya. Cerita Jaka Tarub misalnya, diceritakan didalam cerita Jaka Tarub sedang mengintip bidadari cantik yang sedang mandi di sungai. Kemudian salah satu selendang tersebut ada yang hilang dan ditemukan oleh Jaka Tarub. Kebaikan hati Jaka tarub inilah yang membuat bidadari jatuh cinta dan akhirnya menikah dengan Jaka Tarub. Kejadian Jaka Tarub sedang mengintip bidadari mandi. Hal inilah yang mengandung unsur seksualitas didalamnya. Hal ini jika dibiarkan maka akan merusak pemahaman anak-anak tentang nilai moral mereka ketahui dari cerita Jaka Tarub tersebut. Anak-anak akan berpikir bahwa mengintip orang yang sedang mandi di sungai diperbolehkan jika kita akan menolongnya. Maka disini perlu adanya perombakan terhadap cerita anak yang berkembang di Indonesia. Perombakan terhadap cerita rakyat dapat dilakukan dengan teori dekonstruksi. 
MENGUBAH PARADIGMA

\section{KARYA SASTRA ANAK:}

DEKONSTRUKSI

\section{Hakikat Dekonstruksi}

Dekonstruksi pada awalnya adalah cara atau metode membaca teks. Adapun yang khas dalam cara baca dekonstruktif, sehingga pada perjalanannya selanjutnya dia sangat bermuatan filosofis adalah unsurunsur yang dilacaknya untuk kemudian dibongkar, pertama-tama bukanlah inkonsistensi logis, argumen yang lemah, ataupun presmis yang tidak akurat yang terdapat dalam teks, sebagaimana yang biasanya dilakukan pemikiran modernisme, melainkan unsur yang secara filosofis menjadi penentu atau unsur yang memungkinkan teks tersebut menjadi filosofis. Kurniawan (2017:89) mengemukakan bahwa teori dekonstruksi merupakan sebuah metode membaca teks secara sangat cermat hingga pembedaan konseptual hasil ciptaan penulis yang menjadi landasan teks tersebut tampak tidak konsisten dan paradoks dalam menggunakan konsepkonsepnya dalam teks secara keseluruhan.

Dekonstruksi menurut Derrida merupakan sebuah metode membaca teks secara sangat cermat hingga pembedaan konseptual hasil ciptaan penulis yang menjadi landasan teks tersebut tampak tidak konsisten dan paradoks dalam menggunakan konsep-konsepnya dalam teks secara keseluruhan. Dengan kata lain, teks tersebut gagal memenuhi kriterianya sendiri; standar atau definisi yang dibangun teks digunakan secara reflektif untuk mengguncang dan menghancurkan pembedaan konseptual awal teks itu.
Dekonstruksi memang berpusat pada teks, tetapi paham yang dipegang lebih luas. Teks tidak dibatasi maknanya. Bahkan dekonstruksi juga menolak struktur lama yang telah lazim. Dekonstruksionis menganggap bahwa bahasa teks bersifat logis dan konsisten. Misalkan, sebuah tema besar bahwa kejahatan akan terkalahkan dengan kebaikan oleh paham dekonstruksi tidak selalu dibenarkan. Teori dekonstruksi sastra dapat digunakan unuk membongkar atau mengubah tema cerita secara garis besar dalam cerita rakyat yang mengandung unsur kekerasan dan unsur seksualitas.

\section{Dekonstruksi Sastra Anak: Merombak Tema dan Tatanan Lama}

Dekonstruksi
dilakukan dalam cerita anak di
Indonesia. Dekonstruksi perlu
dilakukan agar sastra anak yaang
berkembanng di Indonesia tidak
mengandung unsur kekerasan.
Dekonstruksi terhadap cerita anak di
Indonesia dilakukan untuk
merombak tatanan lama yang diubah
sehingga cerita menjadi lebih baik
dan dapat bermakna dalam
pembelajaran ana anak.
Dekonstruksi dilakukan dengan cara mengubah tema-tema yang ada didalam cerita anak pada saat ini. Tema-tema lama yang mengandung unsur -unsur seksualitas didalamnya. Tema-tema tersebut diganti dengan tema yang sesuai dengan anak-anak. misalnya cerita Jaka Tarub diubah sehingga adegan mengintip bidadari saat mandi di sungai tidak terlihat. Tema-tema percintaan dengan lawan jenis seharusnya belum diberikan kepada anak-anak bisa diganti dengan tema percintaan terhadap 
keluarga misalnya dengan orangtua, kakak, dan saudara sepupu.

Perombakan yang

dilakukan dengan menggunakan nantinya dapat mengubah nilai moral anak-anak kedepannya. Anak-anak dapat mengambil amanat dari cerita yang mereka baca dan dapat menjadi bekal mereka kedepan. Selain itu, dengan melakukan perombakan terhadap cerita anak di Indonesia kita dapat melihat kebermaknaan cerita anak dalam perkembangan psikologis dan pendidikan karakter anak. Sarumpaet (2017:56) mengemukakan perlu adanya perubahan terhadap karya sastra anak di Indonesia. Perlu adanya perhatian lebih sehingga cerita anak yang berkembang di Indonesia dapat bermakna untuk kehidupan anak. Bagaimana peran dekonstruksi untuk mengubah kebiasaan lama yang telah terjadi sehingga mengalami perubahan yang nantinya akan berdampak positif terhadap perkembangan anak-anak.

\section{Dekonstruksi Sastra Anak: Perlunya Perubahan Kekerasan Pada Sastra Anak}

Dekonstruksi terhadap cerita anak yang mengandung unsur kekerasan perlu dilakukan. Perlu adanya perubahan besar terhadap cerita anak yang mengandung unsur kekerasan. Unsur-unsur kekerasan yang terdapat didalam cerita anak biasanya terdapat komik dan lainlain. Dekonstruksi cerita dapat dilakukan dengan cara mengubah jalan cerita menjadi cerita yang lebih mengenalkan unsur-unsur peembelajaran didalamnya. Cerita tersebut dapat diganti dengan cerita anak yang mengandung rasa toleransi antar teman, antar suku, dan sebagainya. Menghilangkan adegan kekerasan yang ada dalam cerita yang mengandung unsur kekerasan diubah dengan menunjukkan dampak negatif akibat melakukan kekerasan.

Kasus perkelahian antar sesama teman, penganiayaan terhadap guru bisa terjadi kerena pengaruh dari apa yang mereka baca dan apa yang mereka lihat. Anakanak membaca komik yang mengandung unsur kekerasan secara tidak langsung akan meniru apa yang didapat setelah membaca komik tersebut. Komik seperti Naruto, One Piece, Inuyasa, Samurai X banyak diminati oleh anak-anak. komik tersebut bayak mengandung unsur kekerasan yang seharusnya tidak layak untuk dibaca oleh anak-anak. Kasus-kasus seperti inilah perlu adanya perubahan terhadap cerita anak yang mengandung nilai kekerasan. Dekonstruksi terhadap cerita anak dilakukan agar tidak terjadi lagi hal-hal yang dapat merusak perkembangan moral mereka. Winarni (2014:23) mengemukakan bahwa sastra anak mempunyai tiga ciri khas yang penting. Ketiga ciri sastra anak tersebut, yaitu (1) unsur pantangan, penyajian gaya secara langsung, (3) fungsi terapan. Fungsi terapan dalam sastra anak merupakan cerita yang disajikan harus bersifat informatif dan harus mengandung unsur-unsur yang bermanfaat. Jadi, dengan mengubah cerita anak dengan mementingkan fungsi terapannya maka anak-anak akan mendapatkan hal yang bermanfaat bagi kehidupan mereka nantinya. Dekonsruksi yang dilakukan terhadap cerita anak akan membuat paradigma baru sehingga 
dengan adanya paradigma baru inilah sastra anak akan lebih bermakna dalam mencetak generasi muda kedepannya.

\section{MENGUBAH PARADIGMA KARYA SASTRA ANAK: KEBERMAKNAAN}

\section{Kebermaknaan sastra anak: tanpa kekerasan dan seksualitas}

Dekonstruksi terhadap sastra anak akan membuat paradigma baru terhadap sastra anak yang telah ada sebelumnya. Paradigma yang dihasilkan dari proses dekonstruksi akan membuat sastra anak lebih bermakna tanpa adanya unsur kekerasan dan seksualitas. Cerita anak yang tidak mengandung unsur seksualitas dan kekerasan akan menghasilkan pengetahuan baru yang merupakan sebuah tuntunan untuk bekal kehidupan anak-anak kedepannya. Santosa (2002:90) mengemukakan bahwa karya sastra anak banyak sekali mengandung nilai nilai pendidikan yang dapat menjadi bekal anak-anak untuk kehidupan mereka di masa mendatang.

$\begin{array}{lrr} & \text { Kebermaknaan sastra anak } \\ \text { tanpa adanya kekerasan dan } & \text { dan } \\ \text { seksualitas akan membuat anak }\end{array}$
memahami arti kehidupan. Anakanak akan memahami bagaimana cara mereka untuk bersikap terhadap orang tua, teman, keluarga dan orang yang lebih tua. Kebermaknaan yang didapat juga dapat membentuk kepribadian anak dan menuntun kecerdasan emosi anak. Anak-anak dapat memahami konsep diri mereka, membentuk sifat-sifat kemanusiaan yang terdapat dalam diri anak.

\section{Kebermaknaan Sastra Anak: Fungsi Terapan Sastra Anak}

Kebermaknaan sastra anak pasti mengandung fungsi terapan didalamnya. Fungsi terapan inilah yang akan menjadi bekal untuk anak-anak Winarni (2014:54) mengemukakan bahwa fungsi terapan merupakan sajian cerita yang harus bersifat informatif dan mengandung unsur-unsur yang bermanfaat, baik untuk pengetahuan umum, khusus maupun pertumbuhan anak-anak. Fungsi terapan dalam sastra anak tanpa menggunakan unsur kekerasan dan seksualitas ditunjukkan dalam unsur intrinsik yang terdapat didalam cerita anak itu sendiri. Misalnya dari judul Petulangan Simbad akan memberikan informasi tokoh asing. Keasingan itu merupakan bahan informasi bahwa simbad berasal dari daerah Arab-Persia. Selain anak dapat mengetahui nama tokoh-tokoh tersebut, pengetahuan anak akan bertambah tentang negeri asal tokoh itu, apa yang ada didalam negeri tokoh itu, letak negara tokoh itu, apa terkenal di dalam negeri tersebut.

\section{SIMPULAN}

Sastra merupakan ungkapan perasaan seseorang yang dituangkan dalam sebuah tulisan maupun cerita yang dikemas secara menarik pembacanya. Tidak jauh berbeda dengan sastra, sastra anak merupakan ungkapan perasaan seorang anak yang dituangkan kedalam bentuk tulisan dan dinikmati oleh anak-anak. Bentuk sastra anak yang terdapat di Indonesia sangatlah beragam diantaranya seperti puisi, cerpen, novel, dongeng, fabel dll. Dewasa ini banyak sekali cerita anak yang mengandung unsur kekerasan 
didalamnya. komik merupakan salah satu contoh cerita anak yang digemari di dunia tak terkecuali juga di Indonesia. Banyak sekali ditemukan buku komik yang memiliki gambar- gambar dan cerita menyimpang yang tidak layak dikonsumsi oleh pembaca khususnya anak- anak, dalam hal ini kekerasan mendominasi perkembangan komik di Indonesia. Cerita rakyat yang diperuntukkan untuk anak-anak tentu ada yang aman bagi anak dan ada pula yang tidak aman. Meskipun cerita rakyat sebuah cerminan budaya, beberapanya dalam konteks kini malah berpotensi meninggalkan kesan tidak baik karena saratnya beberapa cerita mengandung seksualitas, kekerasan, iri dan dengki. Perlu adanya dekonstruksi sastra untuk mengubah cerita sehinga tidak terdapat unsur kekerasan dan unsur seksualitas dalam cerita anak. Dekonstruksi sastra dilakukan dengan mengubah tema-tema yang berkembang selama ini, serta menghapus adegan yang mengandung unsur kekerasan.

\section{DAFTAR PUSTAKA}

Aminuddin. 2001. Karya Sastra dan Anak-Anak. Malang: Departemen Pendidikan Nasional Universitas Negeri Malang Fakultas Sastra Jurusan Sastra Indonesia.

Dwita. 2018. Sastra Anak dan Metode Penelitian Sastra Anak. (Online), (http://berbagi ilmu .go.id/lamanbahasa/artikel/90 ), diakses 03 Mei 2018.

Fitriani. 2016. Sejarah Sastra dan Perkembangan Sastra Anak di Indonesia (Online), (http://pembelajaransastraanak.go.id/lamanbahasa/artikel/1527), diakses 05 Mei 2018.

Kurniawan, Heru. 2013. Sastra Anak dalam kajian strukturalisme, sosiolohi, semiotika, hingga penlisan artikel kreatif. Yogyakarta: Graha Ilmu.

Lukens, Rebecca. 2013. A Critical Handbook of Children`s Literature. Newyork: longman.

Nafisah. 2018. Sastra Anak Sebagai Pengantar Pemahaman terhadap Dunia Anak.

(Online),(http://sumberpeengetahuansastra.go.id/lamanbahasa/artikel/19), diakses 06 April 2018.

Nurgiyantoro, Burhan. 2016. Sastra Anak Pengantar Pemahaman Dunia Anak. Yogyakarta : Gajahmada University Press.

Sarumpaet. Riris. K. Toha 2017. Metode Penelitian Sastra Anak. Jakarta : Yayasan Pustaka Obor Indonesia.

Sasita. 2018. Gebrakan Pembaharuan Karya Sastra Anak Di Indonesia. (Online), (http://sumberpeengetahuansastra.go.id/lamanbahasa/artikel/19), diakses 07 April 2018.

Sawirta. 2006. Sastra Tradisional Sebagai Pembentuk Karakter Generasi Bangsa (Online), (http://skajianterkinisastra.go.id/lamanbahasa/artikel/19), diakses 19 April 2018.

Silvia. 2016. Karakteristik Cerita Anak Indonesia Dan Perkembangan Cerita Anak Dunia

(Online),

138 | Jurnal Kredo Vol. 2 No. 1 Oktober 2018 
(http://berbagiilmuberbagicerita.go.id/lamanbahasa/artikel/56), diakses 2 April 2018.

Winarni, Retno. 2014. Kajian Sastra Anak. Yogyakarta : Graha Ilmu. 